\title{
THREE MODELS OF POST-COMMUNIST TRANSFORMATION AND LESSONS LEARNED
}

\author{
Mikloš, I.
}

Ivan Mikloš / Former Deputy Prime Minister and Minister of Finance of the Slovak Republic, President of economic think-tank MESA10, Visiting Professor, Central European University, School of Public Policy, Quellenstraße 51 | A-1100 Wien, Austria. Email: miklos@mesa10.org.

\begin{abstract}
The paper analyses the experience of post-communist transformation. It focuses on preconditions and causes of differences in the success of this process in different countries. The paper, in contrast to the traditional basic division of transformation strategies into gradualist and radical, brings a new perspective. Defining a third, spontaneous transformation trajectory, characteristic of countries unsuccessful in transformation. The paper also points to examples of the transition between individual transformation trajectories and strategies (especially on the example of Slovakia and Georgia).
\end{abstract}

Keywords: post-communist transformation; transitional economies; gradualist transformation; radical transformation; spontaneous transformation; reform process; economic system; economic reforms; transition recession; socialist system

JEL Classification: P20, M20

\section{Introduction}

The collapse of the communist system and the disintegration of the communist bloc within a few months three decades ago was a surprise to almost everyone. But not because it happened. Economic, social, ecological, as well as moral decline and overall backwardness had been evident for several decades. It was a shock as to the speed of disintegration and the fact that Moscow and its allies (and vassals) in the communist bloc did not even resist the transfer of power. They did not even try to reach an agreement on some compromise "socialism with a human face". This was obviously due to two factors. On the one hand, Gorbachev's resignation to maintain the communist system and the Moscow bloc by force. On the other hand, the degree of internal disruption in the individual countries of the communist bloc.

After the autumn of 1989 , over the course of a few weeks, the old political, as well as the economic system, collapsed like a house of cards. And with its collapse came an urgent, vital question - how to turn the system of a centrally managed ("planned") economy best 
and quickly into a free market economy. It was not only a political challenge. During the first months and years, it was also an unprecedented intellectual and technical challenge. No one has ever tried to do this before. There was no practical experience (whether good or bad) based on which an optimal procedure could be proposed.

The theory was not and could not be helpful either. Western academic economists could not penetrate the essence of the functioning of the centrally planned economy. Not from the outside, and they were not allowed to examine it from the inside (just as various Western "Kremlin scientists" did not penetrate behind the scenes of communist politics). Meanwhile, economists from communist countries could not openly examine and name those problems which were ideological taboos and which lay at the very essence of the regime's systemic failure (absence of private property, free competition, demand-side pricing, and so on). Thus, it was no coincidence that the Hungarian economist Janos Kornai became the greatest and most respected expert on the functioning of the centrally planned economy. Hungary has had a relatively liberal model of the communist regime since the late 1960s, with a degree of openness to the West and some partial reforms. Although there was a leading role for the Communist Party and central planning, the degree of tolerance for more critical views, travel to the West and openness to it, as well as partial economic changes (more details later) was incomparably higher in Hungary than in other communist countries (except for the former Yugoslavia). This is one of the reasons why the Hungarian system was called "goulash communism".

Kornai made perfect use of this relative freedom. The best proof of this is that throughout the $80 \mathrm{~s}$, he lived for half a year in Budapest and worked as an economist at the Hungarian Academy of Sciences and for half a year in the USA as a full professor at Harvard. In the late 1970s, he wrote the book "The Shortage Economy", published in 1980 in Hungarian and English almost simultaneously. It received considerable acclaim, but it is significant to state that in communist countries, only in Poland and China was it officially published. Although it was translated in Czechoslovakia, it was not officially distributed, only as a study in research institutes. In the Soviet Union, it was distributed only in the form of samizdat.

Despite being the most penetrating and comprehensive analysis of the functioning of the centrally planned economy at that time, this book could not address the most sensitive but also the most important systemic shortcomings of the communist political and economic system. Kornai wanted his book to be published officially, especially in Hungary. So, he had to engage in some form of self-censorship, as he writes in his memoirs (Kornai, 2006). When writing the book, he decided in advance not to write about three things - the Soviet Union and its role, the Communist Party, and its position in society, and how the situation could change if state property gave way to private property. As he writes, "obviously, these were not secondary issues. They played a fundamental role in understanding the socialist system. I did not want to proclaim half-truths about them, but I could not afford to tell the truth. It seemed to me that it would be best if I kept quiet about these issues."

Despite this limitation "The Shortage Economy" played a particularly important role in undermining the communist regime. It became well known and respected among economists and intellectuals during the 1980s, as confirmed several times by the most famous Russian reformer of the early 1990s, Yegor Gaidar. Although the book did not explicitly state this, its clear implicit conclusion was the impossibility of reforming a centrally planned economy and the need for fundamental systemic change. Even more economists 


\section{DISCUSSION}

from the communist countries came to this conviction during the 1980s, including the Polish economist Leszek Balcerowicz. He wrote of his opinion in the 1980s that he "fully shared the ironic prediction of von Mises that effective socialism reform entails a return to capitalism" (Balcerowicz, 2014).

It is thus significant that the first truly comprehensive analysis of the system of functioning in the centrally planned economy was re-published (Kornai, 1992), i.e., more than two years after the fall of communism. At the same time, it was still an analysis of the functioning of the old system. A reform manual simply did not exist after the fall of communism. The difficulty of the situation is beautifully illustrated by the analogy attributed to the Polish dissident Adam Michnik. According to him, the change from a market economy to a centrally planned economy is as simple as changing an aquarium into a fish soup. In the opposite direction, from the centrally planned to the market economy, it is as difficult as changing fish soup into an aquarium.

The first lesson from transformation, then, is that the absence of freedom (not only political and economical, but also academic and intellectual) leads to limited knowledge that makes it difficult to transform from a non-free and undemocratic society to a free, open, and democratic society.

\section{Transformation as a technical and political challenge}

Thus, after the fall of communism, there was no validated or accepted model of transformation. Not even in theory. In principle, however, there were two basic approaches, the proponents of which are still debating which one was better. Proponents of a gradual way of transformation have emphasized that it is first necessary to build the institutions of the new system, that is, the market economy, and only then to dismantle the old system. However, representatives of the radical approach, which also became known as the "shock therapy", argued that systemic change must be as rapid as possible. The old system has de facto collapsed. So, if the change is not fast enough and intertwined in the most important systemic economic issues, there is a risk of chaos, high inflation, and a prolongation of the transition recession.

The transition recession was an unavoidable consequence of decades of the functioning of an inefficient, wholly deformed, and distorted economic system without an internal motivation to increase productivity, efficiency, and innovation: A system of life at the expense of the future that has kicked in huge direct, but also indirect hidden debts and imbalances. The transition recession was not an option but a necessity. It was not caused by the reforms and the fall of the communist regime but by the regime itself. The length and depth of the transition recession, however, depended mainly on the chosen transformation strategy, as well as the degree of deformation and the length of the functioning of the centrally planned economy. The transition recession has also proved to be the reason why transformation has gradually become less of a technical challenge and more of a political problem.

People's motivations for rejecting the communist regime varied. Yet, dissatisfaction with living standards and quality of life prevailed in most post-communist countries. In light of the 
high standard of living in the West, as observed during the fall of the regime, there was a broad expectation for better times. However, in the first months and years after the fall of communism, there was an (unavoidable) transition recession. The associated decline in living standards, disappointment from (unrealistic) expectations led to an increase in frustration and dissatisfaction. This frustration was often aimed at the reformers who tried to make things right and create the conditions for economic growth and, consequently, the growth of living standards.

I belonged from the beginning of the transformation to the supporters of a radical approach. The advantages of which over the gradual transition are now confirmed by all the important empirical data. The more radical and faster the reform process in post-communist countries, the shorter and less profound the transition recession and the lower the rise of unemployment (Treisman, 2014).

However, when trying to answer the question of why some countries have been more successful than others, the speed and complexity of post-communist transformation after the fall of communism will not suffice. Not all countries that have opted for a gradual model have failed. Also, the division into two groups (gradual and radical) is insufficient.

I believe it is much more accurate to divide post-communist countries into at least three groups. Poland since 1990, a year later Czechoslovakia and then Estonia, Lithuania, Latvia and later Slovakia and Georgia belong to the first group, among the countries that have chosen a quick and radical approach. In fact, the gradualist approach was implemented only in Slovenia and Hungary. All other countries (Romania, Bulgaria, Russia, Ukraine, Moldova, and other countries of the former Soviet Union) were characterized (at least at the beginning during the first years of transition) by the absence of any meaningful and thoughtful way of transformation from a centrally planned to a market economy. I am going to call this spontaneous approach transformation.

\section{Institutional vacuum}

It is necessary to realize that after the fall of communism, the old political-economic institutional framework disintegrated very quickly, within a few days or weeks. Formal rules based on the leading role of the Communist Party, on the command economy and central regulation of pricing, production, investment, consumption, credit, the absence of political and economic freedom, political and economic competition, the absence of private property and business ceased to apply.

The old, communist institutional framework was completely inapplicable in the new circumstances since it was based on the complete absence of both political and economic freedom. During communism, not only was there no free and fair political and economic competition but the old institutional framework and rules served to prevent and suppress such competition. The old system of rules thus collapsed, and the new did not exist. Logically an institutional vacuum was created.

And it was the manner in how this institutional vacuum was filled that differentiated the countries in their approach to transformation.

First, let's explain the basic distinctions among the three approaches. 


\section{DISCUSSION}

A rapid, radical approach was that in a truly short time (after several months of preparations, in a single legislative package), several steps were taken in the areas of fiscal and monetary policy, foreign trade and price liberalization. They removed the most important systemic distortions and imbalances, established a macroeconomic balance, and opened the economy to foreign competition. Following the opening of the economy and the establishment of macroeconomic balance, governments continued to pass new legislation and build the institutions needed for a functioning market economy.

The gradualist approach was that such steps were taken slowly, spread over a longer period across several steps.

The spontaneous approach was characterized by helplessness and procrastination. Individual economic policy measures were being taken in response to growing chaos and disorder rather than by pursuing a comprehensive and meaningful strategy.

\section{Gradualist transformation}

The true gradualist approach was applied only in Hungary and Slovenia. Mainly because only in these two countries conditions formed, historically, so that the slower and gradual transition did not turn into a spontaneous transformation. In both countries, opportunities for gradual transformation formed many years before the fall of communism. Slovenia was the smallest and most economically developed part of Yugoslavia. It applied a relatively liberal political and economic model which was independent of Moscow for decades. Also, Slovenia is a small country bordering Italy and Austria. Unlike all other parts of the former Yugoslavia, it has not been marked and hampered by the military conflict after Yugoslavia's disintegration.

The same was true for Hungary. The communist regime had been somewhat liberal and open since the late 1960s. There was a relatively strong small to medium size business class; central planning was not binding but only indicative. Most importantly, Hungary had been gradually introducing several market economy institutions since the late 1960s. In other words, after the fall of communism, Slovenia and Hungary did not have to make certain reforms because they had done so long ago, during the communist regime. The following table shows the time differences of reform measures in Hungary and Czechoslovakia.

Thus, after the fall of communism, all other post-communist countries had only two real alternatives - either rapid and radical or spontaneous transformation. 
Table 1 | Chronology of reforms in Hungary and Czechoslovakia

\begin{tabular}{l|l|l}
\hline Reform measure & Hungary & Czechoslovakia \\
\hline Abolition of binding plans & 1968 & 1990 \\
Abolition of central allocations (quotas) & 1968 & 1990 \\
The first steps towards price liberalization & 1968 & 1991 \\
United currency exchange rate & 1981 & 1991 \\
Entrance to the World Bank and IMF & 1982 & 1990 \\
Private enterprises & 1982 & 1991 \\
Bankruptcy Act & 1982 & 1992 \\
Two-tier banking system & 1987 & 1990 \\
New income tax system & 1988 & 1993 \\
New VAT system & 1988 & 1991 \\
Commercial Code & 1989 & 1991 \\
Liberalization of foreign trade & 1989 & 1991 \\
Unemployment benefit system & 1989 & 1991 \\
\hline
\end{tabular}

Source: Žídek (2017)

\section{Radical transformation}

This approach was first applied in Poland, where a rapid and radical transformation was launched on 1.1.1990. Leszek Balcerowicz became its architect and thus the real pioneer of a successful post-communist economic transformation. Radical transformation (or "emergency policy", as Balcerowicz himself calls it) is mainly based on creating the conditions for the functioning of the new system of an open market economy as soon as possible after the collapse of the old system of a centrally managed economy. To do this, the reform package must include a critical magnitude of change in areas such as removing remnants of central planning, breaking domestic monopolies, introducing freedom of enterprise and liberalizing prices and foreign trade (Balcerowicz, 1995).

A similar reform package was applied a year later (from 1.1.1991) in Czechoslovakia under the leadership of Vaclav Klaus. Since I was involved to some extent in its preparation and implementation ${ }^{1}$, I will explain the logic and functioning of this reform package in more detail. The reform team around Klaus prepared a reform package in a document called the "Economic Reform Scenario". It was approved by the government and then in September 1990 by the parliament. It was implemented on 1.1.1991, exactly one year after a similar Polish reform package.

The economic reform scenario has identified four reform priorities:

- Price liberalization

- Restrictive monetary and budgetary policy

- Liberalization of foreign trade and internal convertibility of the currency

- Fast and extensive privatization

The first three of these four priorities had been launched and implemented since the beginning of 1991 . Before the end of 1990 , they were preceded by the devaluation of the Czechoslovak currency: A three hundred per cent devaluation to roughly the level of the unofficial black market. The vast majority of prices (up to $95 \%$, excluding electricity, gas,

${ }^{1}$ At the time of its preparation in the second half of 1990, I was an adviser to the Deputy Prime Minister of the Slovak Republic responsible for economic reforms. Vaclav Klaus was the Federal Minister of Finance. 


\section{DISCUSSION}

housing, health, education and utilities) have been liberalized, as well as wages. The devaluation made it possible to liberalize foreign trade and open the economy, as imports became significantly more expensive and exports became cheaper so that there was no risk of unsustainable imbalances. Until then, prices were often regulated below cost (especially for basic foodstuffs) and, also, there were shortages, and the prices of liberalized imports were high. After the liberalization of prices, there was a necessary increase in the price level. However, inflation growth declined and stabilized after several months. In January 1991, prices rose by $28.5 \%$, in February by $7 \%$ and in March by $4.5 \%$. Afterwards, the monthly increase in prices stabilized at around two per cent per month. For the whole of 1991 , inflation reached $56.6 \%$, in 1992 it was only $11.1 \%$. The macroeconomic situation was kept under control even in the transitional year of 1990 when inflation reached only $9.7 \%$ (unlike, for example, Poland, where there was exceedingly high inflation in the years leading up to and during the fall of communism, approaching hyperinflation).

The radical transformation model had its own internal logic, and it was important to adhere to all the above-mentioned priorities. If tight monetary and budgetary restrictions were not maintained after price liberalization, inflation would not be brought under control so swiftly. Due to limited money increase through monetary and budgetary policies, price growth hit the demand ceiling, and inflation fell sharply. Liberalization of foreign trade, in turn, opened the economy and allowed the import of hitherto scarce goods, especially from the West. This not only eliminated market scarcity but also established competition. However, for this competition to not be devastating and to be sustainable in terms of the exchange rate and balance of payments stability, price liberalization and foreign trade had to be preceded by currency devaluation to real market levels (i.e., the black-market level of late communist regime). Devaluation (by $300 \%$ ), on the one hand, completely opened the possibility of imports. On the other hand, it made them significantly more expensive. Thus, it increased the competitiveness of domestic producers on the domestic as well as foreign markets (exports become cheaper by devaluation). An example of the devastating consequences for domestic producers of opening the market while strengthening the currency is the unification of Germany and the exchange of East German marks for West Germany marks in a $1: 1$ ratio, which is, in fact, a revaluation.

The current liberalization of prices and foreign trade, together with monetary and budgetary restrictions, have made it possible to eliminate the major systemic shortcomings of the centrally planned economy swiftly while maintaining macroeconomic stability. The key systemic shortcomings that the radical approach has remedied have been scarcity and soft budget constraints. The scarcity was due to excess demand oversupply. Soft budget constraints were due to the absence of real competition and bankruptcy.

Privatization differed from the other priorities of the radical transformation approach. It could not have been done so quickly and certainly not at the same time. Nevertheless, the priority was rapid privatization, especially in Czechoslovakia, which was different from some other post-communist countries (especially Hungary and Poland) in that private enterprise and private ownership did not exist here at all during communism. This was the main reason why in Czechoslovakia (and after the separation of 1.1.1993 continuing in the Czech Republic), in addition to standard privatization through auctions, international tenders, direct 
sales and restitution, non-standard coupon privatization took place. Yet, even rapid privatization takes years. If it is not carried out quickly, in an organized manner with an emphasis on openness, transparency and professionalism, it will take place in the form of so-called spontaneous privatization, even more so than with other reforms.

The situation in Poland and Czechoslovakia differed only in the degree to which relative macroeconomic stability was maintained before the reform. Until the end of November 1989, the Czechoslovak communist regime was very rigid politically but also fairly disciplined economically in terms of maintaining wage and price discipline within a relatively strict budgetary and monetary policy. The transitional mixed government, which ruled from December 1989 until the first free elections in June 1990, continued this restrained fiscal and monetary policy. The result was reasonably low inflation both during the communist era and throughout the transitional period.

In Poland, inflation was higher throughout the 1980s and was triggered mainly by the price wage spiral. Shortage pushed up price growth, which was offset by even higher wage growth (indexation) in the politically weakening regime. This accelerated the price spiral even more. It culminated in 1989, after the first partially free elections in which opposition Solidarity defeated the then monopoly Communist Party. The difference between Poland and Czechoslovakia is best illustrated by the difference in the rate of inflation in the year preceding the start of radical reforms. While in Czechoslovakia it was 9.7\% (1990), in Poland it was 553.6\% (1989). In the first reform year (Czechoslovakia 1991, Poland 1990) it was $56.6 \%$ in Czechoslovakia and $76.7 \%$ in Poland. Besides Poland and Czechoslovakia, a similarly radical transformation approach was used in Estonia, Lithuania, and Latvia, and later, since 2003, in Georgia.

\section{Spontaneous transformation}

In principle, we can say that all other post-communist countries that did not have the preconditions for a successful gradualist approach, such as Hungary and Slovenia, or that did not take a radical approach (such as Poland, Czechoslovakia, and the Baltic countries) found themselves in the process of spontaneous transformation after the fall of communism. We deliberately say, "found themselves". This process was not intentionally and purposefully intended and controlled. Rather, it was the result of helplessness and the absence of a well-thought-out transformation strategy. Thus, a spontaneous transformation took place in all other post-communist countries (except the above mentioned). These are Romania, Bulgaria, Russia, Ukraine, Belarus, Moldova, and other republics of the former Soviet Union². The specificity of Russia is that since the beginning of 1992, under the leadership of Yegor Gaidar, it had tried to install a similar radical concept as Poland two years before and Czechoslovakia a year earlier. However, this attempt was insufficiently complex and vigorous. It ended in failure and a return to spontaneous transformation in less than a year. In Belarus, the chaos of spontaneous transformation in 1991-1994 led to the rise of the authoritarian regime led by Alexander Lukashenko, and in Russia after the chaotic and critical 90 s, to the rise of the authoritarian regime of Vladimir Putin.

2 In principle, this group of countries of spontaneous transformation also includes all the countries of the Western Balkans. Perhaps with the partial exception of Croatia, where a form of (war) delayed gradualist approach might be considered. 


\section{DISCUSSION}

The group of countries of spontaneous transformation is further divided into those which, despite the chaos in the first post-communist years, were later able to transform into functioning market economies and those which have failed so far. The fundamental difference criterion here was the accession to the European Union. This was a decisive stimulator and a tool for carrying out the necessary reforms and overcoming the trap of spontaneous transformation. It is thanks to the accession to the EU that Romania and Bulgaria have succeeded. Among the successful reform countries, we can also include Georgia. Later (after 2003), it managed to accelerate and deepen the necessary reforms even without the support of the European integration process. The story of Slovakia, which we will discuss later, is also specific and instructive.

A common feature of spontaneous transformation is high macroeconomic imbalances, especially inflation. While countries applying a gradualist and radical approach have been successful in establishing macroeconomic equilibrium (especially taming inflation), and also in building a new institutional framework for a functioning market economy, the same cannot be said of countries that have found themselves in spontaneous transformation. The following table comparing the average inflation rate among transitioning countries illustrates this very well.

Table 2 | Average and maximum annual inflation rate in 1991-2002

\begin{tabular}{l|l|l}
\hline Gradualist transformation & Radical transformation & Spontaneous transformation \\
\hline Slovenia: $12.3 \%, 32 \%$ & Czech Rep.: $6.6 \%, 11 \%$ & Romania: $99.8 \%, 256 \%$ \\
Hungary: $18.1 \%, 34 \%$ & Slovakia: $8.3 \%, 13 \%$ & Bulgaria: $155.9 \%, 1058 \%$ \\
& Lithuania: $17.1 \%, 72 \%$ & Russia: $161.4 \%, 875 \%$ \\
& Latvia: $19.2 \%, 91 \%$ & Moldova: $235.0 \%, 1308 \%$ \\
& Poland: $22.3 \%, 45 \%$ & Belarus: $531.6 \%, 2220 \%$ \\
Average: $15.2 \%, 33 \%$ & Estonia: $22.5 \%, 90 \%$ & Ukraine: $696.3 \%, 4735 \%$ \\
& Average: $16.0 \%, 53.7 \%$ & Average: $196.7 \%, 1742 \%$ \\
\hline
\end{tabular}

Source: UN Economic Commission for Europe (2024)

The data speaks for itself. While in the countries of gradual and radical transformation, the average and the highest inflation were similar and not exceedingly high, in the countries of spontaneous transformation, the average inflation in the years 1991-2002 was twelve times higher. The highest inflation was even 52 times higher, on average than in countries with a gradualist transformation and 33 times higher than in countries with a radical transformation.

\subsection{Ukraine as a textbook example of spontaneous transformation}

After the collapse of communism and the Soviet Union, Ukrainian politics, including economic policy, was further governed by old political and economic elites - communists and communist directors of large state-owned enterprises, the so-called "red directors". To understand their specific position, however, it is necessary to go back to the last years of the Soviet Union, the second half of the eighties. In the 1980s, it was becoming clear that the Soviet economy was in decline. Oil prices, after rising in the 1970s, had fallen. The economy based on heavy industry and oil and gas exports stagnated. Soviet technological and economic backwardness was becoming clear. 
In March 1985, the young Mikhail Gorbachev became the General Secretary of the Central Committee of the Soviet Union Communist Party. In other words, the strongest man in the country and in the communist camp. In 1987, he announced the so-called perestroika. It was a mixture of partial political and economic reforms of a system in which, until then, political and economic freedom and the associated institutions of the market economy and parliamentary democracy were completely absent. The result of these partial reforms was even more confusion than before, as well as a huge boom in spontaneous privatization and corruption.

The first reform of 1986 gave large state-owned enterprises relative freedom in foreign trade but did not create any rules to limit the possibility of abusing these new opportunities. The Cooperatives Act, adopted in May 1988, has enabled a wide range of private enterprises to be set up and operate. The law created 2000 unregulated banks, which were "cooperatives" formally. New private enterprises (cooperatives) were most often established by directors of state-owned enterprises. At the end of 1989, lease laws were passed. This allowed the manager of state-owned enterprises to buy them with the revenues of the same enterprises or with the revenues of private enterprises (cooperatives), achieved by tunnelling state-owned enterprises. The commonly used scheme was for state-owned enterprises to buy overpriced inputs from a private enterprise owned by the red director of the state-owned enterprise and to sell the outputs of the state-owned enterprise to the same (or another) private enterprise of the director. So, there was spontaneous mass privatization, which even got its own name. People called it "prichvatizacija", i.e., possessive privatization by business managers from within. Between 1990 and 1991, the Soviet economy de facto collapsed. The central bank printed more and more money, wages grew, and new private banks (cooperatives) became generators of new money. The individual Soviet republics stopped paying taxes to the centre, and in response, the central bank printed even more money. However, most prices in shops remained administratively regulated and fixed. This caused a huge shortage; shops were almost constantly empty, and the grey and black economy flourished.

At the end of 1991, the Soviet Union disintegrated. Boris Yeltsin has been the Russian President since the summer of 1991. He suppressed a coup of hard-line supporters in August 1991 and appointed a new government in the fall of 1991. He himself took the lead and appointed young reformers led by Yegor Gaidar, who became Deputy Prime Minister and Minister of Finance, to key economic positions. This team tried in 1991-1992 to enforce a post-communist transformation program, like the one that had successfully launched in Poland since the early 1990s and in Czechoslovakia since January 1991. He succeeded only in part. This was, on the one hand, because the situation in Russia was more complicated, but mainly due to the lack of sufficient political support from President Yeltsin. Influential red directors, who opposed the tightening of monetary and budgetary policy, also played a major role in curtailing reforms (which resulted in Gaidar's dismissal in December 1992).

In Ukraine, unlike Poland and Czechoslovakia (but also unlike Russia), there had been no attempt at real reform after the fall of communism. Ukraine did not have its Balcerowicz, Klaus, or its Gaidar. In Ukraine, unlike Poland and Czechoslovakia, the Communists were not weaned from political power. This is also related to the fact that there were no lustrations in Ukraine. The new political force fighting for Ukraine's independence, the Ruch 


\section{DISCUSSION}

movement, agreed on a truce with the communists in exchange communist support the establishment of an independent Ukraine. I was a truce that the more politically experienced communists used to control the country. The relative strength of the old and new elites (communists versus Ruch) is beautifully illustrated by the results of the first presidential elections. Kravchuk received $77 \%$ of votes in December 1991, while the leader of the Ruch movement Viaceslav Chornovyl only $23 \%$ of the votes.

In the chaos of the late 1980s and early 1990s, new (or rather old-new) elites formed in Ukraine, mostly from four main segments - the communist nomenclature, the red directors of state-owned enterprises, the secret services members and organized crime. The years of Leonid Kravchuk's presidency (1991-1994) were characterized by economic chaos, hyperinflation and the gradual formation and strengthening of new elites, consisting mainly of the above four categories. The most important source of economic strength for these elites was the tunnelling of state-owned enterprises and state property. However, even the strongest players at that time had not acquired the status and power of oligarchs. In any case, the process of their creation began already in this period.

In 1994 Leonid Kuchma became President. He was the Prime Minister under President Kravchuk and previously one of the largest and most influential red directors. He defeated Kravchuk himself in the election, and at the beginning of his term, in 1994-1995, he looked like a reformist President. The government has started cooperating with the International Monetary Fund and the World Bank. In cooperation with the National Bank of Ukraine led by later President Yushchenko, the government brought inflation under control (fell from $4375 \%$ in 1993 to $342 \%$ in 1995). A new convertible currency, Ukrainian hryvnia (UAH) was introduced, prices were partially deregulated, and foreign trade was liberalized. By reducing the deficit, public finances recovered, and macroeconomic stability was strengthened. The problem was that these changes were under enormous pressure from old structures and old-new "elites". The positive pro-reform period lasted only until 1996, when Prime Minister Pavlo Lazarenko was appointed, and regulatory policies and incentives prevailed over real reforms, liberalization, and deregulation.

Privatization was the factor that contributed the strongest to the emergence of the most influential and richest Ukrainian oligarchs. It was never transparent or competitive; it was controlled by the old-new elites in their favour. Even mass, coupon privatization had not become a tool for the distribution of state property among ordinary people in Ukrainian conditions. Rather it was a tool for concentrating wealth in the hands of some of the richest and most influential. In a chaotic, mismanaged and poorly communicated coupon privatization project, oligarchs bought coupons for a fraction of their real value and then used those coupons to privatize state-owned enterprises for an even smaller fraction of their real value. The reform potential of the "Orange Revolution" in 2004-2005 was completely thwarted due to the unpreparedness and reluctance of its leaders, President Yushchenko and Prime Minister Tymoshenko, to make real changes, and also by disagreements and animosities between them.

Then came the reign of President (and former Prime Minister) Yanukovych. He used his enhanced presidential powers to usurp political and economic power, making him and his family one of the strongest oligarchic groups in the country. On the eve of Euromaidan (or 
the Revolution of Dignity, as called by the Ukrainians themselves), Ukraine was a textbook example of a corrupt, oligarchic state with dysfunctional institutions: A state captured by influential oligarchs, a state in which there was formal democracy and a market economy. In reality, there was no real political competition, no independent courts, no independent and professional central bank, no protection of property rights and so on. It was a state in which corruption was ubiquitous, where real political and economic power was not in the hands of the government and parliament, but in the hands of several groups of the strongest oligarchs (among them President Yanukovych and his group, during his presidency). They owned not only a large part of the economy but also almost all influential media (especially television). They welded influence over the government, parliament, law enforcement institutions, and courts.

The real political and economic power is thus in the hands of the oligarchs. They control the government, parliament, courts, large state-owned enterprises, and other important institutions, which should be independent and protect the public interest. Before Euromaidan in 2014, Ukraine was a textbook example of what social scientists call "state capture", i.e., the capture and control of the state by interest groups (oligarchs).

For the process of reforms in Ukraine after $2014^{3}$, let me just mention that the system is gradually, albeit slowly and with difficulty, changing into a functioning market economy. The greatest credit for this goes to the departure from Russia and the support of the country's pro-Western direction by most of the population (after the annexation of Crimea and the aggression in eastern Ukraine). Also, credit goes to the support that the country receives from the EU and the Western Allies, as well as the effective pressure from the International Monetary Fund (without whose support Ukraine would not have avoided default).

\subsection{Consequences of spontaneous transformation}

Based on the Ukrainian example, we can suggest that the main consequence of the application of spontaneous post-communist transformation is the emergence of a corrupt oligarchic system with the absence of free and fair competition in the political and economic spheres. Free and fair competition is a prerequisite for liberal democracy and a functioning, competitive market economy. The state plays a key role in creating the institutional framework (rules of the game) that shapes the behaviour of economic and political entities. These rules must protect free and fair competition and punish anyone who wants to abuse their economic and/or political position and power for their own interests.

In every post-communist country, the period of the first years after the fall of communism was characterized by a degree of chaos, absence of rules of the game, corruption, a weak state, the rise of organized crime, extortion, and the like. In this sense, no post-communist country has avoided giving the adjective "wild" to the 1990s.

However, if the new elites deliberately and purposefully built new rules of the game and a new institutional framework to protect fair and just political and economic competition, these difficulties were overcome. Countries that have succeeded have a liberal democracy and a functioning market economy and are successfully converting to rich, Western European countries. It is no coincidence that these are also those countries that have been successful

${ }^{3}$ For more information about post Euromaidan reforms see Mikloš, Ivan and Kukhta, Pavlo eds: Reforms in Ukraine after Revolution of Dignity, SAGSUR, Kiev, 2019. 


\section{DISCUSSION}

in the process of Euro-Atlantic integration. They have joined NATO and the European Union, and some of them have joined the eurozone. The logic of this relationship is that reforms were a condition for entry. Meanwhile, potential entry was a strong stimulus and impetus to accelerate reforms.

Ukraine was one of the countries in which the new elites did not enforce the new institutional framework, in which the old-new elites used the acquired economic and political power to prevent the creation of such rules of the game. Yet, there are always some formal and informal rules. However, the necessary preconditions for prosperity are that these rules maximize and protect economic freedom that they are enforceable and enforced, and that there are no major differences between formal and informal rules. In principle, this also applies to political freedom. Although, it is a bit more complicated, and there are exceptions to the relationship between prosperity and political freedom.

In economic terminology, we distinguish two types of economic behaviour: Rent-seeking and profit-seeking. The difference in these types of behaviour will also help us to understand the difference between a functioning market economy based on fair and free economic competition and a corrupt and oligarchic economy. Rent-seeking is such economic behaviour where income and benefits are achieved through the abuse of political and/or economic power, for example, by abusing a monopoly position or by passing a law that discriminates against one group and favours others. This can also occur with nontransparent privatization below cost in favour of a politically related privatizer, misuse of inside information and the like. Rent-seeking includes revenue from corruption, but it is also a practice that may not bring immediate direct income but leads, for example, to a reduction in competition and a consequent rise in prices.

Profit-seeking means achieving income by increasing competitiveness in open and fair markets, in free and fair competition. The winner is the one who is better, more competitive, who can produce and sell products or provide services at higher quality and lower prices than its competitors. Using the terminology of rent-seeking and profit-seeking, we can say that successful post-communist countries are those which, during the first decades after the fall of communism, were able to minimize the space for rent-seeking and maximize the space for profit-seeking. In this sense, Ukraine was one of the countries that mostly failed in this endeavour. At the same time, a corrupt oligarchic system does not mean that corruption concentrates only at the level of oligarchs. It is much more complicated and much worse. Corruption is ubiquitous; it is integral to the functioning of the system, which is overgrown by it, in every direction.

A dysfunctional and corrupt system is not only dysfunctional in the protection of the public interest. It actively serves as a tool for destroying the public interest to the benefit of narrow groups or individuals. For example, law enforcement institutions and courts have not only been inactive in protecting property rights and the rule of law. They have become an active instrument of lawlessness and have been (and still are) being abused to infringe property rights. Likewise, the tax authorities have not only been institutions that have tolerated tax evasion, but their representatives themselves have organized large-scale tax evasion. Control and regulatory institutions have inadequately controlled and regulated; they themselves have actively invented new permits and licenses, which they have then issued 
for bribes and the like. The most serious and at the same time one of the most difficult problems is the overgrowth of the commanding resorts with organized crime.

The consequences of spontaneous transformation must ultimately be reflected in a lagging economy. This is best illustrated by the example of Ukraine. It was considered one of the most promising parts of the former Soviet Union after the fall of communism, regarding the chances of successful transformation into a functioning and competitive market economy. It had everything, a young, educated workforce, strong industrial but also scientific and technological potential, many raw materials (iron ore, coal, oil, gas), the most fertile soil in Europe (chernozem), an excellent geographical position. It was in the middle between the future poles of development and growth. The lag behind developed countries was considerable but not greater than in most other post-communist countries.

In the early 1990s, when Ukraine emerged as an independent state, its economic level was like that of Poland, Romania, or the Baltic post-Soviet republics (Estonia, Lithuania, Latvia).

Unfortunately, this relatively promising starting position did not translate into the expected results. Today, Ukraine's position in comparison with other post-communist countries is as follows:

Table 3 | GDP per capita in purchasing power parity $(1992,2019$, in \%)

\begin{tabular}{l|l|l}
\hline Country & $\mathbf{1 9 9 2}(\%)$ & $\mathbf{2 0 1 9}(\%)$ \\
\hline Ukraine & 100 & 100 \\
Latvia & 93 & 238 \\
Romania & 101 & 232 \\
Poland & 104 & 257 \\
Slovakia & 133 & 254 \\
\hline
\end{tabular}

Source: IMF, World Economic Outlook 2020

The consequences and costs of spontaneous transformation are, of course, reflected in non-economic indicators as well. Ukraine has low wages and pensions, high emigration, a low average life expectancy. A generally low standard of living and quality of life, especially in relation to the potential that the country has had but still has. Unfortunately, it is the people who have to pay a very high price for a spontaneous transformation. 


\section{DISCUSSION}

\section{Second wave reforms and reform latecomers}

From the point of view of our division of basic transformational post-communist strategies (gradual, radical and spontaneous), it is interesting to look at exceptional examples of countries that have managed to make the transition. We mentioned that Bulgaria and Romania were on a trajectory of spontaneous transformation in the 1990s. Thanks to the EU integration process, they finally managed to push through the necessary reforms and avoid the trap of long-term spontaneous transformation ${ }^{4}$. The stories of Georgia and Slovakia are also interesting. We are going to examine them briefly.

\subsection{Georgia}

Georgia was in complete disarray after the collapse of the Soviet Union in 1991. There was a civil war in the country; the government did not control $20 \%$ of its territory, corruption and bribery were the norms, the average annual inflation in 1991-2002 reached $2672 \%$ with the highest annual value of 22 286\%. In 2003, after the "Rose Revolution", Mikhail Saakashvili became President of Georgia. He had been a young lawyer who studied in the USA and was mayor of the capital Tbilisi before being elected President. The new President and the new government immediately embarked on reforms based on a radical transformation strategy. Not only did they carry out the first wave of reforms based on macroeconomic stabilization (in a similar way to Poland and Czechoslovakia in the early 1990s) swiftly, but they also embarked on the so-called second wave of reforms in areas such as the tax system, privatization, energy reform, police reform and so on. All reforms were guided by a strategy of maximizing economic freedom, openness, and fair competition. One of the goals of the reforms was also the fight against corruption.

Saakashvili and his government colleagues justified the need for a radical approach by saying that "Georgia was, in fact, a failed state, so reforms had to be more radical and aggressive than in other Eastern European countries" (Saakashvili \& Bendukidze, 2014). The results of Saakashvili's reforms have been very impressive, with Georgia fundamentally changing for the better over the nine years of his rule. While the average annual inflation in the years 1991-2002 was $2672 \%$, in the years $2003-2013$ it was $6.4 \%$. The average annual economic growth in the years 2004-2012 was $7 \%$. In the ranking of the quality of the business environment, Georgia moved from 112th to 8th place in the same period; in the ranking of perception of corruption (Transparency International) from 134th place to 51st place; in the ranking of economic freedom (Heritage Foundation) from 91st place to 21 st place.

Saakashvili's style of governing was controversial, and in some cases, his critics blamed him for undemocratic actions and decisions. The fact is, however, that, in principle, the democratic exercise of his power has been confirmed after nine years of rule. By the peaceful transfer of power to the opposition in 2012 after the election in which he lost. And

\footnotetext{
${ }^{4}$ With a degree of simplification, we could say that with delay and with the help of EU membership, Romania has then moved more towards radical transformation. Bulgaria has chosen a more gradual approach. The result was different economic and convergence dynamics in favour of Romania.
} 
the fact is that Georgia is still benefiting from his reforms, not least because the governments that came after Saakashvili's defeat did not undermine successful reforms.

\subsection{Slovakia}

Slovakia is a different but also an interesting example of the transition between individual transformation strategies. During the forty years of the communist regime, but also during its fall and the first three years of transformation, Slovakia was part of Czechoslovakia. It formed a smaller and economically less developed part of Czechoslovakia. It was fortunate for Slovakia that during the first years of the transformation, it was a part of Czechoslovakia. This meant that Slovakia was a part of a radical transformation prepared and led by a group of reformers around Vaclav Klaus in the federal government. The Slovak reformers participated in this project only marginally. We can argue that if Slovakia were an independent state during the fall of communism, its reform trajectory would most likely be spontaneous rather than radical.

Indirectly, this became clear soon after the division, which took place on 1.1.1993. Between 1992 and 1998, during the two governments of the populist Prime Minister Vladimir Meciar, no reforms took place in Slovakia. Corruption flourished, macroeconomic imbalances grew, and the country was isolated both politically and economically. The only reform that progressed was privatization. It was executed by distributing assets (including large, profitable state-owned enterprises) to people close to the government and the government coalition at symbolic prices. Foreign investors were completely excluded from privatization. The government also abused its position to restrict media independence and fair political competition. The result was the exclusion of Slovakia from integration into the OECD (where the other neighbouring V4 countries joined in the 1990s), the exclusion from the start of accession negotiations to the EU and NATO (again, unlike other V4 countries, Slovenia, and the Baltic countries). In 1997, US Secretary of State Madeleine Albright declared Slovakia the "black hole of Europe".

Thus, in 1993-1998, Slovakia showed all the important features of spontaneous transformation. Unlike countries such as Ukraine or Georgia, it still benefited from the radical transformation it underwent in 1990-1992 as part of Czechoslovakia. This reflected particularly in much more favourable macroeconomic developments, although imbalances gradually increased in this area as well.

In 1998, there was a political change. During the two governments of Mikulas Dzurinda 5 in 1998-2006, the reform and integration process was restored.

The first government (1998-2002) was overly broad, consisting of up to nine political parties. Its most important ambition was to catch up with the integration gap with its neighbours in the V4, especially regarding the accession to the EU. Also, the government had re-established macroeconomic equilibrium, reduced the public finance deficit, rehabilitated large state-owned banks, and launched privatization of large state-owned enterprises and state-owned banks through open international tenders to attract large, foreign strategic investors. Dzurinda's second government in 2002-2006 was much more

${ }^{5}$ In both of them, I had the honour to be the Deputy Prime Minister for the Economy, and in the second in the years 2002-2006 also the Minister of Finance. 


\section{DISCUSSION}

homogeneous. It consisted of four centre-right political parties that agreed on the need for fundamental, radical reforms of the second generation. Besides further consolidating macroeconomic stability and continuing transparent privatization, these included, in particular, radical tax reform, fiscal decentralization, pension reform, labour market reform, social system reform and health care reform (Mikloš, 2014).

The reforms of Dzurinda's governments (especially the latter, in 2002-2006) have brought rapid positive results which exceeded expectations. Slovakia had the highest cumulative economic growth of all EU-27 countries in the years 2000-2012. Unemployment fell from almost $20 \%$ to less than $10 \%$. The general government deficit decreased significantly (from $12.3 \%$ to $2.1 \%$ of GDP), and public debt fell rapidly (from $50.3 \%$ to $27.9 \%$ of GDP). The risk of poverty decreased (from $13.3 \%$ to $10.9 \%$ ), and Slovakia achieved the fastest convergence progress of all post-communist countries. Between 2004 and 2008, in GDP per capita in purchasing power parity, we approached the average of EU-27 by $16 \%$ (from $57 \%$ to $73 \%$ of the EU-27 average), while Hungary by $1 \%$, the Czech Republic by $3 \%$ and Poland about $5 \%$. While at the time of the division of Czechoslovakia in 1993, the Slovak economic level was only $63 \%$ of that of the Czech Republic, in 2008 , it was already $90 \%$.

The effect of radical reforms on investors' perception of the country is best seen in the speed of Slovakia's rating change. Back in 2000, Slovakia had a rating (according to S\&P) of three levels below the Polish and four degrees below the Czech and Hungarian. In 2005, Slovakia already had the highest rating in the V4, one level higher than the Czech Republic and Hungary and two levels higher than Poland. In 2004, Slovakia was declared the most reformed country in the world by the World Bank.

On 1 May 2004, together with our neighbours in the V4, Slovenia and the Baltic countries (plus Cyprus and Malta), we joined the EU in the first wave of expansion. As of 1.1.2009, Slovakia, as the only V4 country, has also become a member of the eurozone. In five to six years, the reforms of M. Dzurinda's governments had fundamentally changed the country's image. From the black hole of Europe, Slovakia has become the Tatra economic tiger.

The end of this story is not so optimistic. From 2006 to 2020 (with less than a two-year break from 2010 to 2012), the anti-reform populist Fico ruled in Slovakia. The effect of the reforms would have gradually faded anyway. However, this trend was further accelerated by the fact that Fico and his governments distorted and destroyed several reforms while implementing hardly any new reforms. In addition, the government was a generator of corruption. As a result, from 2012 to 2013, Slovakia is again lagging in convergence with the EU average. The business environment is deteriorating, the country is also falling in other rankings and is increasingly threatened by the middle-income trap. Although Fico lost power in 2020 and the new government declared a return to reforms and the fight against corruption, the prospects for its declared goals are still very uncertain. Not least because of the corona pandemic and the related economic crisis. So, the Slovak experience is reminiscent of a swing - from radical to spontaneous transformation, then back to radical and again to spontaneous. 


\section{Conclusions}

In my opinion, the most important experiences from the process of post-communist transformation described above could be summarized as follows. It depends a lot on history, geography, and size. Yet, even more, important is strong leadership that can, under certain conditions, overcome the limitations of history, geography, and size. History had played an important role in the post-communist transformation in the sense that those countries that had (before communism) historical experience (albeit brief) with democracy and/or a market economy (free business and private ownership) were usually more successful in post-communist transformation and rather avoided spontaneous transformation. If also, they had historical experience with their own statehood, which was suppressed by the communist regime (as was the case in the Baltic countries), then this was all the more true.

Geography also plays an important role. The closer (geographically) the countries are to advanced democracies with open-market economies, the stronger are the influences and ties in trade, economy, social, infrastructure, but also in intellectual ties, culture, media and others.

The size of the country is also related to this, in at least three ways. First, a small country in the neighbourhood of larger, developed, and rich countries (V4 except for Poland, Slovenia, and the Baltic countries) is much more affected by them than a large one. Secondly, in a small country, the necessary changes from top to bottom are easier to enforce. Thirdly, there are also smaller concerns about small countries in terms of the cost of their accession to the EU. And EU accession is another crucial factor supporting successful transformation, with historical, geographical, and size preconditions being among the most crucial for EU accession.

Despite the importance of history, geography, and size, I believe that the most important prerequisite is leadership. To be able to take advantage of historical, geographical, and size preconditions, or in their absence to overcome this limitation, it is crucial that there are reformers and political leaders who have the vision, will and courage to carry out the necessary reforms. Reforms are never easy, especially because they mean a change to the unknown and thus a risk. People have always had aversion to risk. It is a normal human quality based on which we have survived as humanity. But the world is constantly changing. With it, our society must change. Reforms have been, are and will always be necessary and inevitable. Thus, post-communist reforms were not unique in themselves, but only in the extent and intensity of change, which was given by the degree of deformation of the old system and its sudden collapse.

\section{References}

Balcerowicz, L. (1995). Socialism, Capitalism, Transformation. Central European University Press.

Balcerowicz, L. (2014). Poland. In: Aslund, A., \& Djankov, S. (eds.). The Great Rebirth. Lessons from the Victory of Capitalism over Communism. Peterson Institute of International Economics.

Kornai, J. (1992). The Socialist System. Clarendon Press.

Kornai, J. (2006). By Force of Thought. Irregular Memoirs of an Intellectual Journey. Massachusetts Institute of Technology. 


\section{DISCUSSION}

Mikloš, I. (2014). Slovakia. In: Aslund, A., \& Djankov, S. (eds.). The Great Rebirth. Lessons from the Victory of Capitalism over Communism. Peterson Institute of International Economics.

Saakashvili, M., \& Bendukidze, K. (2014). Georgia. In: Aslund, A., \& Djankov, S. (eds.). The Great Rebirth. Lessons from the Victory of Capitalism over Communism. Peterson Institute of International Economics.

Treisman, D. (2014). The Political Economy of Change after Communism. The Great Rebirth. Lessons from the Victory of Capitalism over Communism. Peterson Institute of International Economics.

Žídek, L. (2017). From Central Planning to the Market. CEU Press, Budapest - New York.

The discussion paper passed the review process. | Received: February 25, 2021; Revised: March 25, 2021; Accepted: April 28, 2021; Published: June 1, 2021. 